\title{
Web Server Berbasis ATmega 128 Untuk Monitoring dan Kontrol Peralatan Rumah
}

\author{
Sigit Pramono ${ }^{1}$, Eka Wahyudi ${ }^{2}$, Luthfi Hendra Lukmana ${ }^{3}$ \\ 1,2,3 Sekolah Tinggi Teknologi Telematika Telkom Purwokerto \\ 1,2,3 Jalan D.I. PanjaitanNomer 128, Purwokerto 53147, Indonesia \\ Email korespondensi: sigit@st3telkom.ac.id
}

\begin{abstract}
Abstrak - Penggunaan mikropengendali untuk mengendalikan perangkat yang ada di rumah tentu menjadi salah satu penerapan prinsip kerja yang praktis dan fleksibel.Mikropengendali dapat digunakan untuk memudahkan dalam mengendalikan lampu ruangan, pemantauan suhu, dan pengendalian sistem penggerak tirai.Dengan memanfaatkan modul jaringanNM7010A TCP/IP Starter Kit maka aplikasi rumah tersebut dapat dikendalikan melalui jaringan intranet. Pada mikropengendali ATmega128, data akan diproses dan dieksekusi untuk mengendalikan sistem kerja keseluruhan rangkaian. Dari hasil pengujian membuktikan bahwa mikropengendali dapat berperan sebagai Embedded Server untuk mengendalikan lampu, pengaktifan kanal Analog to Digital Converter (ADC) yang digunakan untuk memantau suhu.Hasil pengujian terhadap LM35 menunjukan bahwa rata-rata error konversi sebesar $0,64 \%$. Untuk mengeksekusi sistem melalui jaringan TCP/IP diperlukan waktu tunda antara 0,5 sampai 1,2 detik.
\end{abstract}

Kata Kunci - Webserver, Mikropengendali ATmega128, NM7010A, TCP/IP,Perangkat Rumah

\begin{abstract}
Using the microcontroller to control the house applications would be one practical application of the principles and flexible working. The microcontroller can be used to make easier to control the room lights, temperature monitoring and control the drive system curtain. By utilizing a NM7010Anetwork module TCP / IP Starter Kit so the home applications can be controlled via the intranet. At ATmega128 microcontroller data will be processed and executed to control the whole circuit. From the test results prove that the microcontroller can be function as an Embedded Server to control the lights, activation of channel Analog to Digital Converter (ADC) that is used for temperature monitoring. From the testing result for LM35 is shown that average of error convertion is $0,64 \%$. To control the system via TCP / IP network is required the delay time between 0,5 until 1,2 second.
\end{abstract}

Keyword - Webserver, Microcontroller ATmega128, NM7010A , TCP/IP, home aplications

\section{PENDAHULUAN}

Untuk menciptakan sebuah sistem tersebut diperlukan perangkat yang dapat bersinsergi dan sinkron satu dengan yang lain. Perangkat tersebut berfungsi sebagai sebuah antar muka, pengolah data, dan juga pengendali perangkat sistem dengan memanfaatkan jaringan TCP/IP.Dari dasar tersebut pemanfaatan mikropengendali untuk mengendalikan dan memantau sistem dapat diterapkan untuk mendukung kinerja dan memeberikan kemudahan bagi masyarakat [1].Dari penjelasan di atas dapat disimpulkan bahwa agar lebih mempermudah seseorang dalam mengendalikan dan memantau perangkat pada suatu rumah dengan memanfaatkan jaringan maka perlu dibangun sebuah sistem untuk mengendalikan perangkat-perangkat tersebut, dimana sistem yang digunakan merupakan pemanfaatan mikropengendali sebagai kendali utama yang digunakan sebagai Embeded Server. Artinya server yang tertanam pada mikropengendali sehingga saat pengguna membutuhkan data dan instruksi maka mikropengendali akan menyediakan serta mengirimkan data tersebut. Aplikasi perangkat elektronik yang akan dirancang adalah saklar untuk mengendalikan lampu, pemantauan suhu ruangan dengan pemanfaatan kipas untuk meredam suhu yang terlalu tinggi, dan aplikasi motor sebagai penggerak tirai. Pemilihan ketiga aplikasi tersebut didasarkan dengan memaksimalkan fungsi yang ada pada mikropengendali yaitu Input/Output untuk kendali lampu, fungsi Analog To Digital Converter (ADC) Channel sensor suhu LM35, dan pengaktifan Pulse Width Modulation (PWM) untuk menggerakan motor.

Untuk mengendalikan perangkat pada sistem rumah tersebut digunakan komputer sebagai pengendali utama melalui jaringan TCP/IP. Instruksi yang akan diberikan ke mikropengendali dikirim melalui TCP/IP Starter Kit yaitu modul jaringan NM7010A yang berfungsi sebagai jembatan antara mikropengendali dengan jaringan TCP/IP. ATMega 128 akan berperan sebagai pembaca data instruksi yang diberikan kemudian mengeksekusinya. Dengan instruksi yang dikirimkan melalui jaringan TCP/IP maka pengguna dapat mengendalikan dan memantau perangkat yang ada di rumah melalui jaringan intranet.Penelitian ini ditujukan untuk mengetahui 
sistem pengendalian dan pemantauan melalui jaringan TCP/IP terhadap mikropengendali yang dijadikan sebagai Embedded Server.Dengan demikian maka penulis bermaksud untuk merancang dan membuat suatu sistem untuk mengendalikan dan memantau perangkat rumah melalui jaringan TCP/IP dengan memaksimalkan fungsi dari mikropengendali sebagai pengendali utama. Alat ini diharapkan akan lebih membantu dan mempermudah untuk mengendalikan dan memantau perangkat yang ada di rumah.Jurnal penelitian ini disusun sebagai berikut yaitu BAB I menjelaskan pendahuluan, BAB II menjelaskan metodologi penelitian, BAB III menjelaskan hasil penelitian, BAB IV menjelaskan kesimpulan dan saran.

\section{METODOLOGI PENELITIAN}

Penelitian ini dilakukan berdasarkan metode ilmiah dengan tahapan studi leteratur, perumusan masalah, perancangan dan pembuatan sistem, pengujian sistem, dan kesimpulan seperti ditunjukan pada Gambar 1

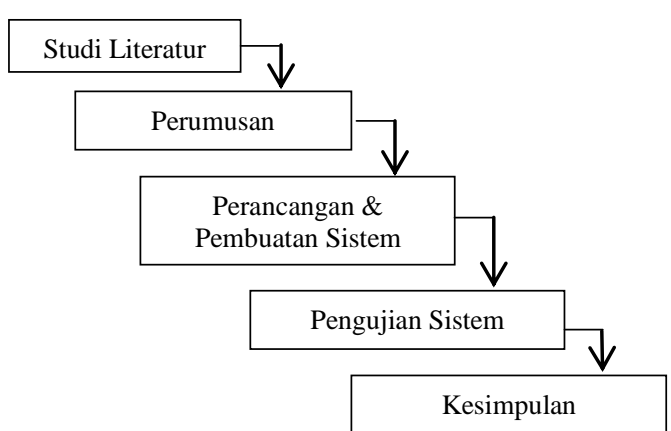

Gambar 1. Diagram Blok Metodologi Penelitian

\section{A. Perancangan dan Pembuatan Sistem}

Sistem tersusun dari beberapa blok, diantaranya adalah mikropengendali ATmega 128, TCP/IP Starter Kit, Liquid Crystal Display (LCD), sensor suhu LM35,sensor Light Dependent Resistor (LDR), driver relay lampu, driver motor DC dan rangkaian catu daya. Masing-masing rangkaian tersebut memiliki peranan dan fungsinya masing-masing pada sistem kendali dan monitoring perangkat rumah. Gambar blok diagram sistem ditunjukkan pada Gambar 2 .

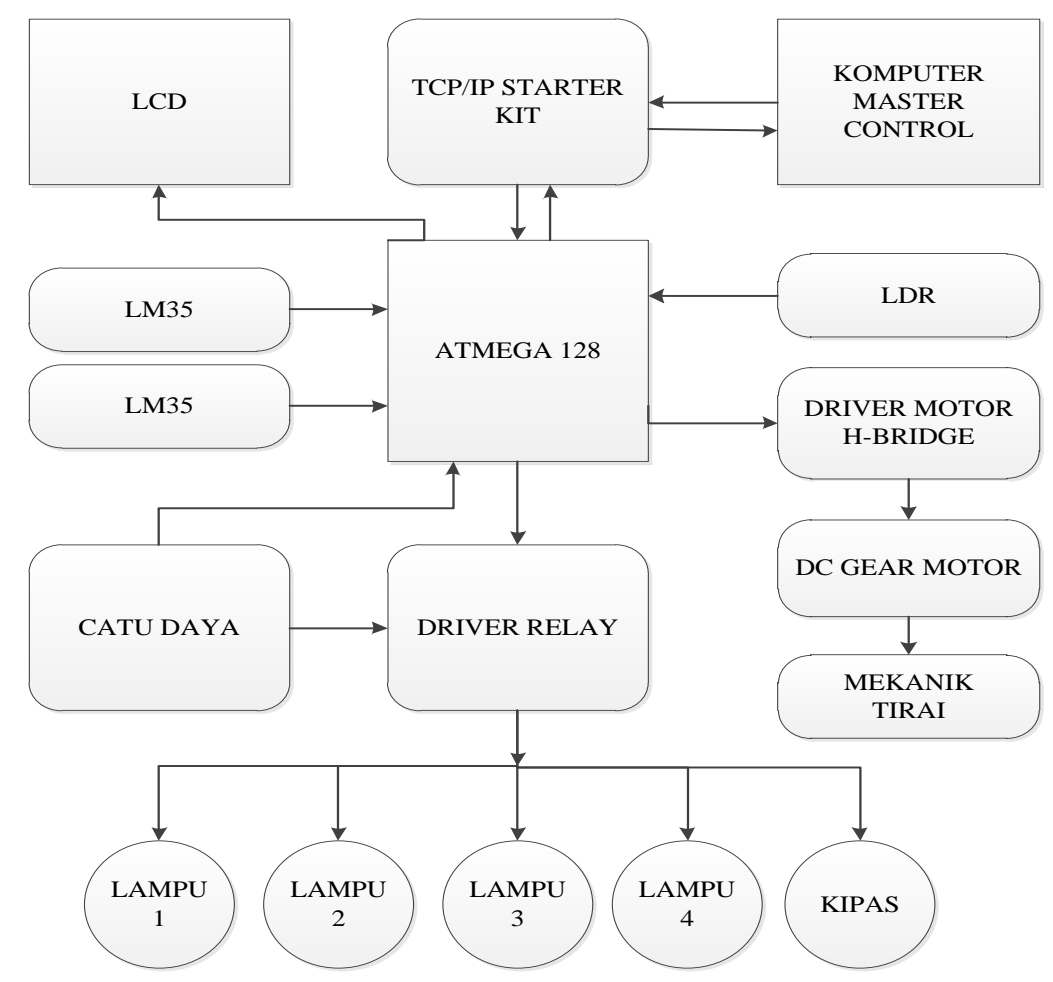

Gambar 2. Diagram Blok Sistem Alat Pengendali

Keseluruhan sistem akan dikendalikan oleh mikropengendali yang berfungsi sebagai embedded server yaitu sebagai pengolah data dan instruksi yang diberikan melalui jaringan TCP/IP. Masing-masing rangkaian akan terhubung dengan port yang ada pada mikropengendali sehingga sistem dapat berjalan sebagaimana mestinya.

\section{B. Perancangan Perangkat Keras}

1. Sistem minimum ATmega 128
Rangkaian sistem mimimum ATmega 128 dilengkapi dengan kristal $8 \mathrm{Mhz}$, rangkaian reset dan rangkaian AREF seperti pada Gambar 3. 


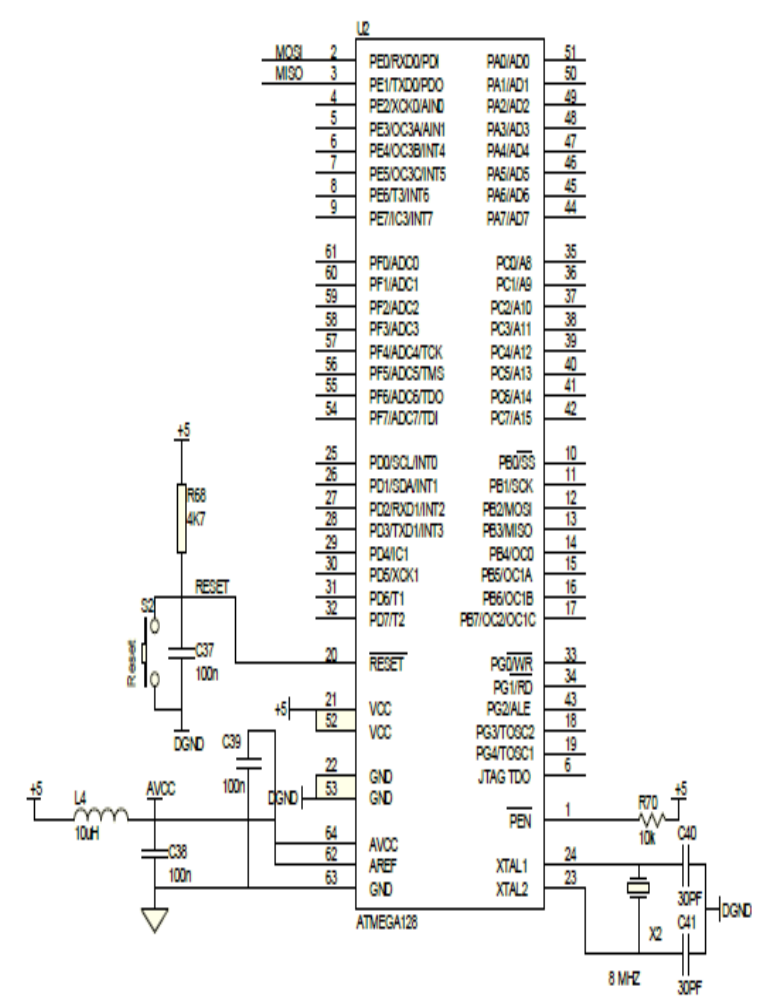

Gambar 3. Rangkaian Sistem minimum ATmega 128

Mikropengendali ATmega 128 merupakan mikropengendali 8-bit teknologi CMOS dengan konsumsi daya rendah yang berbasis arsitektur enhanced RISC AVR. Beberapa fitur utama yang tersedia pada ATMega 128 diantaranyaAnalog to Digital Converter 10 bit sebanyak 8 input. CPU 8 bit yang terdiri dari 32 register umum (General Purpose Register), SRAM sebesar 4 Kbyte.Memori Flash sebesar 128 Kbyte dengan kemampuan read while write.EEPROM sebesar 4 Kbyte yang dapat diprogram saat operasi serta Frekuensi clock maksimum $16 \mathrm{MHz}^{[2,3]}$

\section{Modul TCP/IP NM 7010A}

Transmission Control Protocol/Internet Protocol (TCP/IP) adalah satu set aturan standar komunikasi data yang digunakan dalam proses transfer data dari satu komputer ke komputer lain di jaringan komputer tanpa melihat perbedaan jenis hardware. Protokol TCP/IP selalu berevolusi seiring dengan waktu, mengingat semakin banyaknya kebutuhan terhadap jaringan komputer dan Internet. Pengembangan ini dilakukan oleh beberapa badan, seperti halnya Internet Society (ISOC) TCP/IP mempunyai beberapa layer, layer-layer itu adalah .

1. IP (internet protocol) yang berperan dalam pentransmisian paket data dari node ke node. IP mendahului setiap paket data berdasarkan 4 byte (untuk versi IPv4) alamat tujuan (nomor IP). Internet authorities menciptakan range angka untuk organisasi yang berbeda. Organisasi menciptakan grup dengan nomornya untuk departemen. IP bekerja pada mesin gateway yang memindahkan data dari departemen ke organisasi kemudian ke region dan kemudian ke seluruh dunia.

2. TCP (transmission transfer protocol) berperan didalam memperbaiki pengiriman data yang benar dari suatu klien ke server. Data dapat hilang di tengah-tengah jaringan. TCP dapat mendeteksi error atau data yang hilang dan kemudian melakukan transmisi ulang sampai data diterima dengan benar dan lengkap.Sockets yaitu merupakan nama yang diberikan kepada paket yang menyediakan akses ke TCP/IP pada kebanyakan system ${ }^{[4]}$.

Pemanfaatan modul jaringan TCP/IP Starter Kit berfungsi untuk menghubungkan antarmuka mikropengendali dengan web kontrol melalui interface RJ45. Pada penggunaannya untuk menampilkan data dari mikropengendali dibutuhkan jeda waktu. Saat dijalankan program tersebut akan me-reset modul NM7010A secara hardware, mengaktifkan fungsi interupsi mikropengendali dan melakukan inisialisasi modul NM7010A pada mode komunikasi ${ }^{2} \mathrm{C}$.

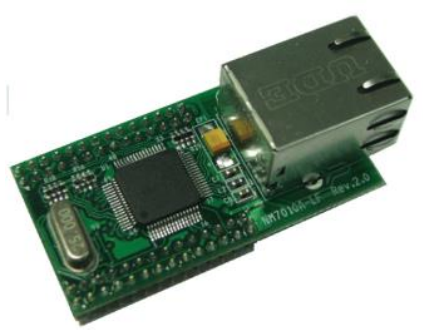

Gambar 4. Modul TCP/IP NM7010A

\section{Sensor Suhu LM35}

LM35 adalah sensor suhu berupa rangkaian terintegrasi (IC) dengan tegangan keluaran yang berbanding lurus terhadap suhu dalam derajad Celcius. Sensor ini dapat beroperasi pada suhu dengan rentang $-55^{\circ} \mathrm{C}$ hingga $150^{\circ} \mathrm{C}$, rangkaian seperti pada Gambar 5.

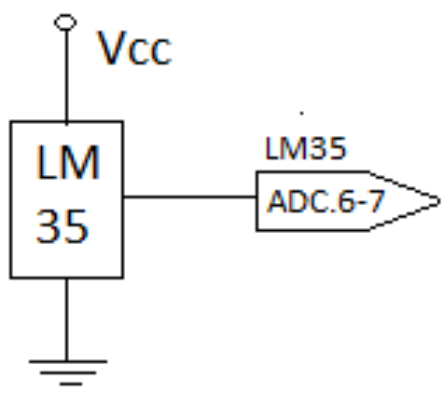

Gambar 5. Rangkaian Sensor LM35

LM 35 memiliki skala linier $10 \mathrm{mV} /{ }^{\circ} \mathrm{C}$, yang berarti bahwa setiap kenaikan suhu $1^{\circ} \mathrm{C}$ akan menaikkan tegangan sebesar $10 \mathrm{mV}$. [4] Secara matemetis tegangan keluaran dari sensor LM35 dapat dirumuskan sebagai berikut. 


$$
V_{L m a 5}=\text { Suhu } x 10 \mathrm{mV}
$$

4. Rangkaian Sensor Light Dependent Resistor (LDR)

Rangkaian sensor LDR berfungsi untuk mendeteksi cuaca gelap atau terang, dengan komponen utama yaitu LDR dan resistor. Rangkaian didesign LDR dekat Vcc dan R1 dekat ground agar mendapatkan nilai tegangan keluran yang ekstrim.Konfigurasi seperti pada Gambar 6

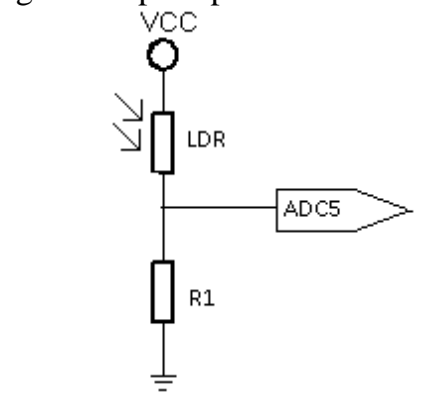

Gambar 6. Rangkaian Sensor LDR

Ketika LDR terkena cahaya nilai resistansinya mengecil kecil dalam ordo $\mathrm{k} \Omega$, dan sebaliknya bila dalam kondisi gelap atau tidak terkena sinar nilai resistasinya membesar dalam ordo $M \Omega$. Tegangan keluaran dapat dirumuskan menggunakan prinsip resistor pembagi tegangan yaitu

$$
V_{L D R}=\frac{R_{L D R}}{\left(R_{L D R}+R_{1}\right)} \times V C c
$$

\section{Rangkaian Driver Lampu}

Rangkaian driver lampu berfungsi sebagai penggerak kontrol hidup atau matinya lampu dengan komponen utama transitor, Relay dan Dioda seperti pada Gambar 7.

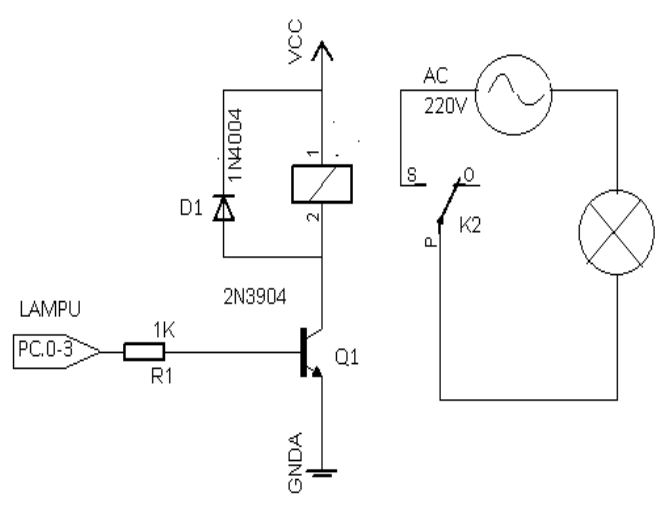

Gambar 7. Rangkaian Driver Lampu

Transistor difungsikan sebagai saklar untuk mengontrol arus yang mengalir ke relay dengan memanfaatkan daerah saturasi dan cut off. Relay berfungsi sebagai titik isolasi antara tegangan PLN $220 \mathrm{~V}$ dan rangkaian webserver

Ketika pin PC.0 dalam kondisi logik "0" maka tidak ada arus basis $(\mathrm{IB} \approx 0)$, transistor dalam kondisi mati (cut off), sehingga tidak ada arus yang mengalir ke emitor $(\mathrm{IC} \approx 0)$. Kondisi seperti ini menyerupai saklar terbuka. [5]

Sebalinya pada saat pin PC.0 mengeluarkan logik "1" akan mengakibatkan arus pada basis $\left(\mathrm{I}_{\mathrm{B}}\right)$, selanjutnya transistor berubah ke kondisi saturasi yang mengakibatkan timbulnya arus pada kolektor $\left(\mathrm{I}_{\mathrm{C}}\right)$. Kondisi seperti ini menyerupai saklar tetutup, lilitan dalam relaymenjadi elektromagnet [6]. Sehingga Switch mekanik akan bergerak, lampu mendapatkan tegangan $220 \mathrm{~V}$

\section{Rangkaian Driver Kipas}

Rangkaian driver kipas berfungsi sebagai penggerak kontrol hidup atau matinya kipas dengan komponen utama transitor, Relay dan Dioda seperti pada gambar 8 .

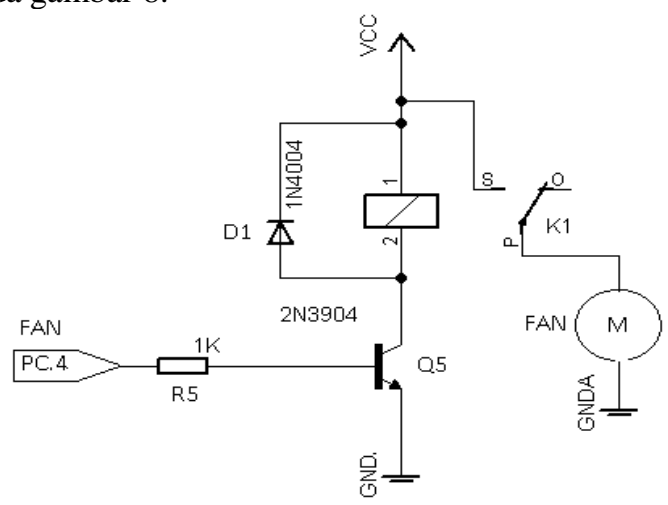

Gambar 8. Rangkaian Driver Kipas

Pada saat pin PC.0 mengeluarkan logik "1" akan mengakibatkan arus pada basis $\left(\mathrm{I}_{\mathrm{B}}\right)$, selanjutnya transistor berubah dari kondisi cut off ke kondisi saturasi yang mengakibatkan timbulnya arus pada kolektor $\left(\mathrm{I}_{\mathrm{C}}\right)$. Kondisi seperti ini $\mathrm{V}_{\mathrm{CE}} \approx \mathrm{Vcc}$ menyerupai saklar tetutup, lilitan dalam relay menjadi elektro magnet sehingga Switch mekanik akan bergerak. Kipas mendapatkan tegangan dari Vcc dan berputar.

\section{Rangkaian Driver Motor DC}

Rangkaian driver motor DC dengan model $H$ Bridge dibangun dengan empat buah transistor, untuk mengatur arah dan kecepatan putaran seperti pada Gambar 9. 


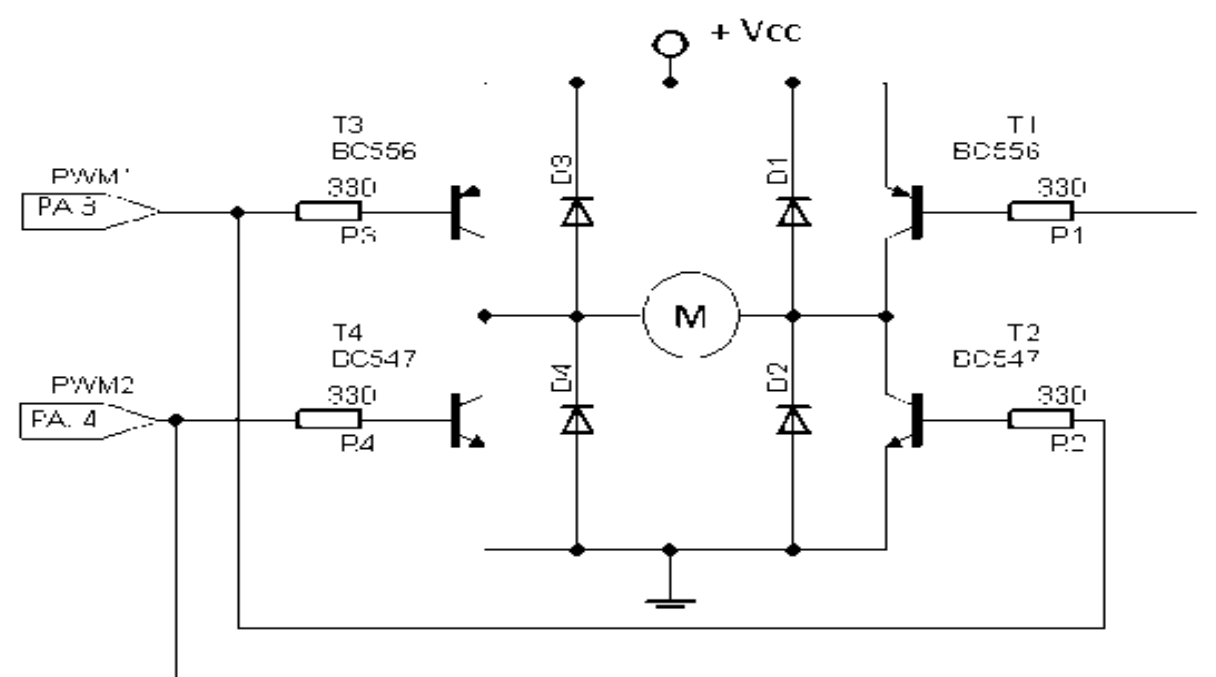

Gambar 9. Rangkaian Driver Motor

Prinsip kerjanya motor DC berputar searah dengan jarum jam bila transistor 2 dan transistor 3 aktif yaitu dengan cara memberikan logika high pada kaki basis transistor tersebut. Sedangkan untuk berputar berlawanan dengan jarum jam maka harus mengaktifkan transistor 1 dan transistor 4 dengan cara memberikan logika high pada kaki basis transistor tersebut. Kondisi atau keadaan lainnya tidak valid (motor tidak berjalan). Sedangkan untuk pengaturan kecepatannyamenggunakan teknik PWM atau dengan cara merubahbesarnya lebar pulsa (duty cycle) yang ditrigerkan ke basis.

\section{Perancangan Perangkat Lunak}

Perancangan perangjat lunak seperti pada diagram alir Gambar 10, dapat dijelaskan sebagai berikut.

1. Inisialisasi meliputi Inisialisasi modul jaringan,socket, protokol tcp/ip, Aktifasi interupt dan Deklarsi variabel.

2. Program mengambil status dari socket 0 .

3. Bila status socket $0=$ established $(06 \mathrm{~h})$ maka:

a. Membaca buffer $R x$ dari modul NM7010ALF

b. Bila data yang diterima adalah perintah "GET" maka program akan menyimpan suffix yang mengikuti perintah tersebut ke dalam variabel Shtml.

c. Jikabuffer $R x$ belum kosong maka program akan kembali ke langkah 8.a.

d. Jika buffer $R x$ sudah kosong maka program mengirimkan http 192.168.0.5

e. Program akan menghapus isi variabel Shtml, lalu menutup socket 0 dan kembali ke langkah 2.

4. Bila status socket $0=$ wait connection close (07h) maka program akan menutup socket 0 dan kembali ke langkah 2.

5. Bila status socket $0=$ connection closed $(00 \mathrm{~h})$ maka program membuka port $80 \mathrm{~h}$ socket 0 dan mulai mendengarkan jaringan dari socket 0 , lalu program kembali ke langkah 3 .

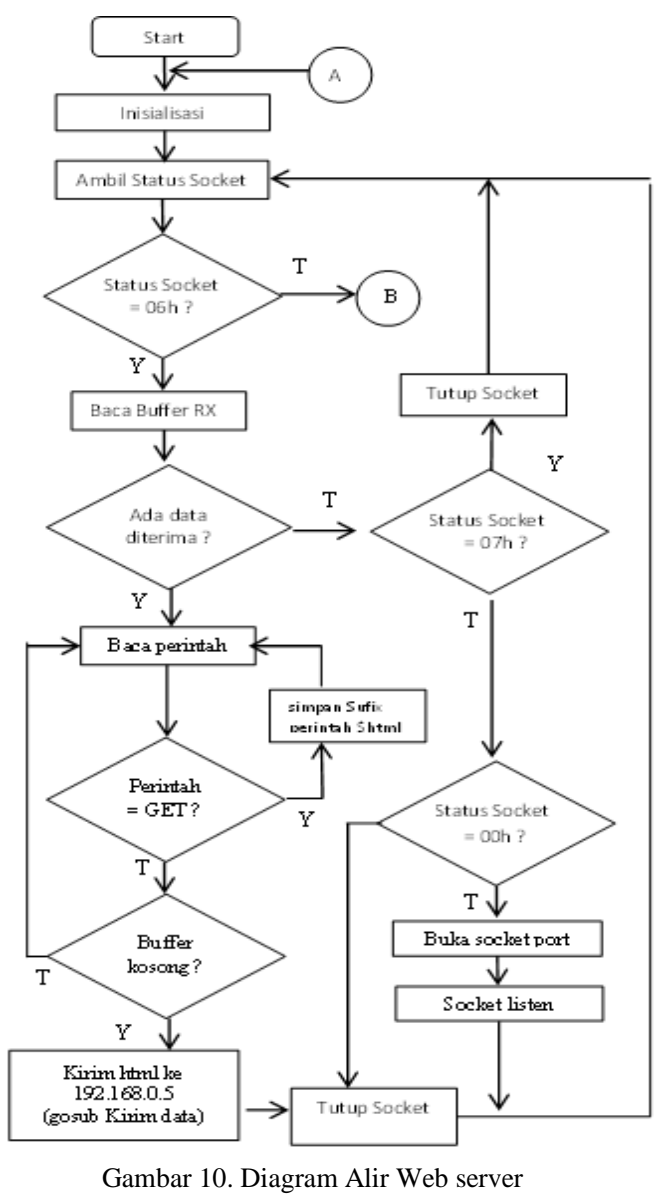

6. Bila langkah 2 status socket 0 bukanestablished (06h) maka jalankan diagram alir Gambar 11. 


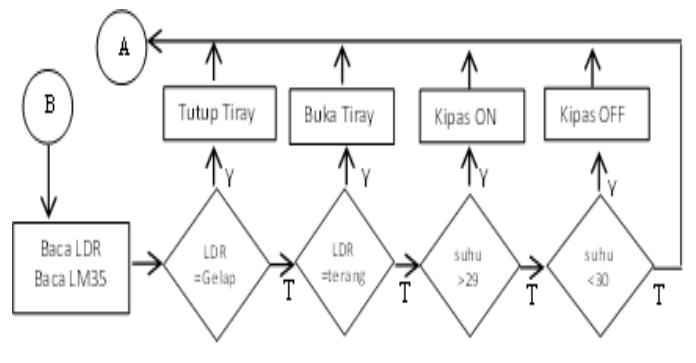

Gambar 11. Flowchart Tirai dan Kipas

7. Membaca nilai LDR dan membaca suhu LM35:
a. Bila LDR gelap maka tutup tiray.
b. Bila LDR terang maka buka tiray
c. Bila Suhu $>29$ Kipas ON.
d. Bila Suhu <30 kipas OFF
e. Kembali ke langkah 1

\section{HASIL PENELITIAN}

\section{A. Pengujian $A D C$}

Pengujian ADC ini bertujuan untuk membandingkan kinerja ADC ATmega128 dengan perhitungan. Sebelumnya ADC dikonfigurasi untuk ADC 10 bit (1024 step) dengan tegangan referensi 5V. Nilai ADC dapat dihitung dengan persamaan :

Nilai $A D C=\frac{\text { Tegangan masukan }}{1024} \times 5$ volt

Masukan ADC0 diberi tegangan dari $263 \mathrm{mV}$ sampai 403 mv secara acak diambil 15 sampel. Grafik hasil pengujian seperti pada Gambar 12.

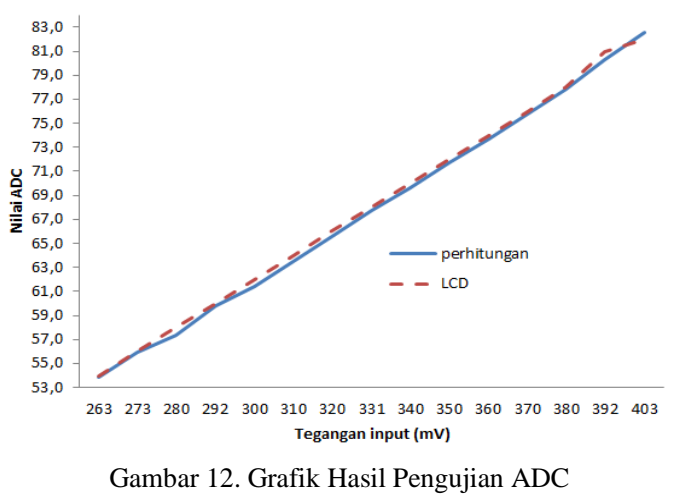

Nilai simpangan konversi ADC dari -0,99 sampai dengan 0,53 dengan nilai rata-rata simpangan konversi $=-0,3$. Sedangkan tingkat error konversi ADC dari $-1,41 \%$ sampai dengan $0,65 \%$ dengan rata rata $-0,41 \%$

\section{B. Pengujian Sensor Suhu LM35}

Pengujian ini akan membadingkan antara suhu pada tampilan LCD yang berasal dari 2 buah sensor LM35 dengan termometer air raksa. Rentang suhu pengujian pada suhu ruang yaitu dari $27^{\circ} \mathrm{C}$ hingga $35^{\circ} \mathrm{C}$ dengan kenaikan $1^{\circ} \mathrm{C}$. Grafik hasil pengujian LM35 seperti pada Gambar 13.

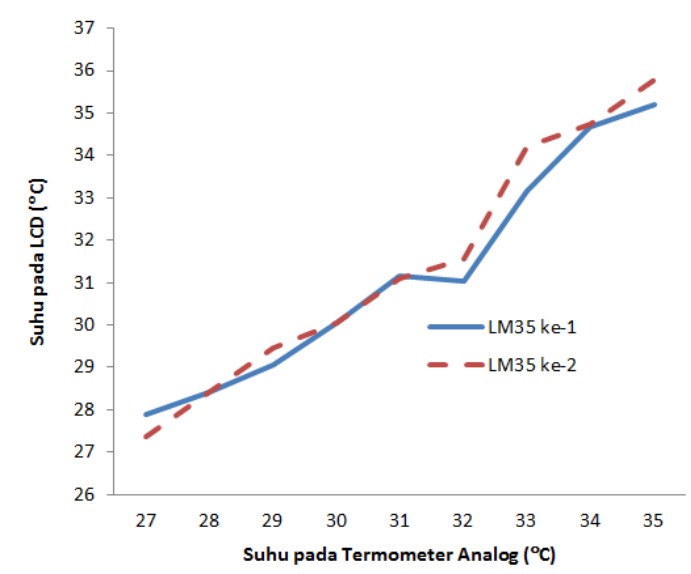

Gambar 13. Grafik Hasil Pengujian Sensor LM35

Sensor LM35 ke-1 memiliki nilai simpangan konversi suhu dari -0,96 sampai dengan 0,89 dengan nilai rata-rata simpangan konversi $=-0,12$. Sedangkan tingkat error konversi suhu dari $-3,0 \%$ sampai dengan $3,3 \%$ dengan rata rata $0,26 \%$.

Sensor LM35 ke-2 memiliki nilai simpangan konversi suhu dari $-0,43^{\circ} \mathrm{C}$ sampai dengan $1,2^{\circ} \mathrm{C}$ dengan nilai rata-rata simpangan konversi $=0,18$ Sedangkan tingkat error konversi suhu dari $-1,3 \%$ sampai dengan 3,6\% dengan rata rata $0,64 \%$.

Sedangkan simpangan konversi LM35 ke-1 di bandingkan dengan LM35 ke-2 dari $-1,05^{\circ} \mathrm{C}$ sampai dengan $0,53^{\circ} \mathrm{C}$ dengan nilai rata-rata simpangan konversi $=-0,23^{\circ} \mathrm{C}$.

\section{Pengujian Sensor LDR}

Pengujian sensor LDR bertujuan untuk mendapatkan nilai tegangan keluaran serta nilai ADC pada saat LDR dalam kondisi tearang dan gelap. Hasil pengujina sepertii pada Tabel 1 dibawah ini.

Tabel 1. Hasil Pengujian Nilai ADC LDR

\begin{tabular}{ccccc}
\hline No & $\begin{array}{c}\text { Kondisi } \\
\text { LDR }\end{array}$ & $\begin{array}{c}\text { R } \\
\text { LDR }\end{array}$ & Vout $(V)$ & Nilai ADC \\
\hline 1 & Terang & $23 \mathrm{k}$ & 1,05 & 213 \\
2 & Gelap & $1 \mathrm{M}$ & 4,50 & 941 \\
\hline
\end{tabular}

Berdasarkan hasil pengujian, pada kondisi terang resistasi LDR kecil yaitu $23 \mathrm{k}$ dengan tegangan keluaran 1,05 V dan nilai ADC 213. Sebaliknya pada kondisi gelap resistasi LDR besar yaitu $1 \mathrm{M}$ dengan tegangan keluaran 4,5 V dan nilai ADC 914.

Nilai ADC pada saat gelap dipergunakan untuk menutup tirai dan nilai ADC saat terang untuk parameter membuka tirai.

\section{Pengujian Driver Lampu}

Pengujian rangkaian driver lampu bertujuaan untuk menguji respon dari relay pada saat masukan pin C0 sampai C3 diberi input logika, adapun hasil pengujian seperti pada Tabel 2 dibawah ini. 
Tabel 2. Hasil Pengujian Driver Lampu

\begin{tabular}{cccccccc}
\hline \multicolumn{3}{c|}{ Masukan Pin } & \multicolumn{4}{c}{ Teg. keluran Relay (V) } \\
\hline C3 & C2 & C1 & C0 & R4 & R3 & R2 & R1 \\
\hline 0 & 0 & 0 & 1 & - & - & - & 220 \\
0 & 0 & 1 & 0 & - & - & 220 & - \\
0 & 1 & 0 & 0 & & 220 & - & - \\
1 & 0 & 0 & 0 & 220 & - & - & - \\
\hline
\end{tabular}

Setelah dilakukan pengujian, pada saat masukan pin C0 diberi logika "1", transistor 1 aktif yang mengakibatkan lilitan dalam relay menjadi elektro magnet. Sehingga Switch mekanik akan bergerak, tegangan jala-jala 220v mengalir ke terminal lampu dan lampu menyala. Rangkaian driver ini jg berfungsi sebagai isolasi antara rangkaian kontroller dengan tegangan $220 \mathrm{~V}$.

\section{E. Pengujian Driver kipas}

Pengujian driver kipas bertujuan untuk mengetahui kinerja rangkaian dan untuk mengukur tegangan keluaran dari driver kipas. Setelah dilakukan pengujian didapatkan hasil seperti pada Tabel 3.

\begin{tabular}{ccc}
\multicolumn{2}{c}{ Tabel 3. Hasil Pengujian Driver Kipas } \\
\hline Masukan & \multicolumn{2}{c}{ Keluaran } \\
PA.4 & $\mathrm{V}_{\text {out }}(\mathrm{V})$ & Gerak kipas \\
0 & 0 & diam \\
1 & 12 & berputar \\
\hline
\end{tabular}

Pada saat PA.4 diberi logika " 1 " transistor 5 aktif yang mengakibatkan lilitan dalam relay menjadi elektro magnet, kontak mekanik akan bergerakmenjadi close, sehingga tegangan dari Vcc mengalir ke kipas. Tegangan keluaran sebesar $12 \mathrm{~V}$ dan tidak ada drop pada kontak mekanik relay.

\section{F. Pengujian Driver Motor DC}

Pengujian driver motor DC bertujuan untuk mengukur keluaran tegangan dari rangkaian driver motor dan untuk menguji pergerakan motor DC. Langkah pengujiannya yaitu dengan cara memberi tegangan $12 \mathrm{~V}$ pada pin Vcc serta memberi logika masukan PA.4 dan PA.4. Setelah dilakukan pengujian rangkaian driver motor diperoleh hasil seperti pada Tabel 4.

Tabel 4. Hasil Pengujian Driver Motor DC

\begin{tabular}{c|c|c|c}
\hline \multicolumn{2}{c|}{ Masukan } & \multicolumn{2}{c}{ Keluaran } \\
\hline PA.4 & PA.3 & V $_{\text {out }}(\mathbf{V})$ & Gerak Motor \\
\hline 0 & 0 & 0 & diam \\
0 & 1 & 11,5 & kanan \\
1 & 0 & $-11,5$ & kiri \\
1 & 1 & 0 & diam \\
\hline
\end{tabular}

Ketika PA.3 diberi logika"1" dan PA.4 logika "0" tansistor 2 dan 3 aktif sehingga motor bergerak ke kanan. Sebaliknya bila PA.3 diberi logika "0" dan PA.4 logika "1" tansistor 1 dan 4 aktif sehingga motor bergerak ke kiri. Tegangan keluaran dari driver mengalami penurunan karena adanya drop tegangan pada transistor.

\section{G. Pengujian modul TCP/IP}

Pada pengujian ini modul jaringan dihubungkan dengan sebuah komputer melalaui kabel UTP cross.IP address pada komputer dan embeded webserver harus satu jaringan (NetID). Pada peengujian ini digunakan subnet 255.255.255.0 IP address komputer 192.168.0.5 dan IP Embeded web server 192.168.0.8

Pengujian konektifitas TCP/IP dengan cara melakukan ping dengan membuka command promt untuk mengetahui kestabilan koneksi dengan menggunakan jaringan tersebut. Hasil pengujian koneksi pada TCP/IP ditunjukkan pada Gambar 11.

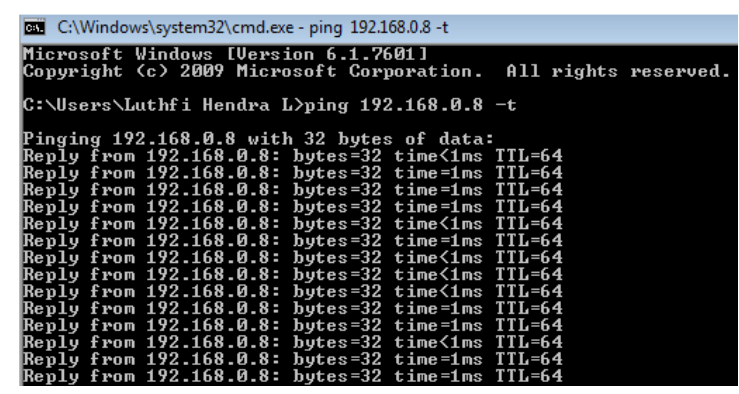

Gambar 11. Pengujian Koneksi TCP/IP

Berdasarkan pengujian didapatkan pada pengiriman data 32 bytes diperlukan waktu kurang dari $1 \mathrm{~ms}$ dan TTL $=64$. Parameter tersebut stabil dan tidak adanya disconection. Sehingga dapat disimpulkan bahwa perancangan Web Server Berbasis Embadded Ethernet telah berhasil terhubung stabil dengan komputer.

\section{H. Pengujian sistem secara keseluruhan}

Pengujian sistem keseluruhan yaitu melihat dan mengamatiweb server ATmega128 yang meliputi:

1. Lima button untuk mengendalikan empat buah lampu dan untuk menggerakan motor tiray.

2. LM35 yang merupakan sensor suhu digunakan untuk mengukur suhu ruangan sebanyak dua buah dan kontrol kipas.

3. Sensor LDR atau sensor cahaya digunakan untuk memicu pergerakan motor untuk membuka dan menutup tirai.

Tampilan dari webbroserhttp://192.168.0.8 seperti pada Gambar 13. 


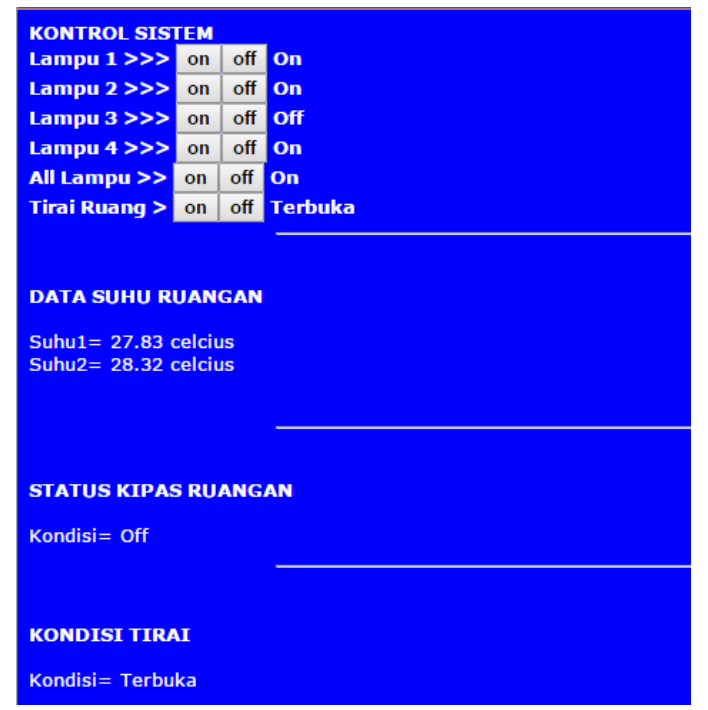

Gambar 13.Hasil Pengujian Sensor LM35

Hasil pembacaan sensor suhu melalui jaringan TCP/IP merupakan hasil pembacaan terakhir kali saat dilakukan refresh. Dari hasil pengujian dapat diketahui bahwa rentang instruksi yang dikirimkan dan dieksekusi melalui jaringan TCP/IP oleh mikropengendali adalah sebesar 0,5 sampai 1,2 detik.

\section{PENUTUP}

\section{A. Kesimpulan}

Dari hasil analisa dan pengujian keseluruhan sistem pada penelitian dengan judul "Web Server berbasis ATmega 128 untuk Monitoring dan Kontrol Peralatan Rumah" dapat disimpulkan sebagai berikut.

1. Untuk mengaplikasikan sistem dengan menggabungkan fungsi mikropengendali yaitu Analog to Digital Converter (ADC), Input/Output (I/O) dan Pulse Width Modulation (PWM) melalui jaringan TCP/IP dibutuhkan waktu tunda sebesar 0,5 sampai 1,2 detik dengan pemberian interupsi.

2. Hasil pengujian konversi ADC simpangan dari $-0,99$ sampai dengan 0,53 dengan nilai ratarata simpangan konversi $=-0,3$. Sedangkan tingkat error konversi ADC dari $-1,41 \%$ sampai dengan $0,65 \%$ dengan rata rata $-0,41 \%$

3. Hasil pengujian sensor LM35 ke-1 memiliki tingkat error konversi suhu dari $-3,0 \%$ sampai dengan $3,3 \%$ dengan rata rata 0,26 . Sensor LM35 ke-2 memiliki nilai tingkat error konversi suhu dari -1,3\% sampai dengan 3,6\% dengan rata rata $0,64 \%$.

4. Berdasarkan pengujian ping dari komputer ke webserver pada pengiriman data 32 bytes diperlukan waktu kurang dari $1 \mathrm{~ms}$ dan TTL sebesar 64.

\section{B. Saran}

Untuk mengembangkan dan meningkatkan kinerja dari penelitian tersebut maka saran yang diberikan oleh penulis adalah sebagai berikut :

1. Gunakan jenis sensor suhu SHT11 sebagai alternatif untuk penggukuran suhu sekaligus kelembaban pada ruangan yang dipasang pada pin SDA dan SCL mikropengendali.

2. Penambahan sensor dan aktuator pada untuk pengendalian menujuSmart home.

\section{DAFTAR PUSTAKA}

[1] Rizki Matra Alfian. Jurnal Penelitian. Web Server Berbasis Embadded Ethernet Untuk Sistem Kendali dan Monitoring Jarak JauhPada Ruang Penyimpan Barang-Barang Berharga. Universitas Diponegoro, 2006.

[2] Syahrul. Mikropengendali AVR ATMega 8535. Edisi Pertama. Bandung : Informatika, 2012.

[3] Syahrul. Pemrograman Mikropengendali AVR Bahasa Assembly dan C. Edisi Pertama. Bandung : Informatika, 2014.

[4] Oscar Rachman dan Gin Gin Yugianto. TCP/IP Dalam Dunia Informatika dan Telekomunikasi. Edisi Pertama. Bandung: Informatika, 2008.

[5] Wibawanto, Hari. Elektronika Dasar. Edisi Pertama. Jakarta : Elek Media Komputindo, 2008.

[6] Harso Adjie. Aplikasi Mikroprosesor Untuk Mengontrol Lampu Penerangan. Edisi Pertama. Jakarta : Elek Media Komputindo, 2004. 